change in optical activity. A sample of high digestive power ( $1: 40,000)$, shows a reaction very nearly neutral.

4. Pepsin tends to approach nearer to the actual character of a protein (possibly a glycoprotein) with increasing proteolytic activity.

DETrort, MICHIGAN

[Contribution from the Chemical Laboratory, Universtity of IOWA.]

\title{
THE EFFECT OF NEUTRAL SALTS UPON THE ACTIVITY OF PTYALIN.
}

By EIBERT W. Rockwoov.

Received October 24, 1918 .

The original purpose of the investigation was to determine the effect of small amounts of ammonium salts upon the activity of ptyalin, but it was later extended to include a comparison with the influence of other neutral salts. It is a continuation of work previously reported ${ }^{1}$ on auxoamylases, or activators of amylolytic enzymes. Because of interruptions which will delay the work for some time, it seems best to publish these results now.

The methods used were essentially as described in the previous article (loc. cit.). Digestion of portions of a boiled starch solution was carried on at $38^{\circ}$ under the same conditions in the presence of toluene. At intervals, $25 \mathrm{cc}$. were pipetted off, heated with an excess of Fehling's solution, the precipitated oxide filtered out and, after dissolving, its amount determined by addition of an excess of potassium iodide and titration of the freed iodine by decinormal sodium thiosulfate.

The salts used were either the chemically pure, neutral compounds as purchased or were made by neutralizing known amounts of the corresponding acids with ammonium hydroxide. Neutrality of the digesting mixture was maintained by the use of a dialyzed litmus solution. Determinations were made in duplicate and only the averages of closely agreeing ones are given. Except in the same series different specimens of saliva were employed and therefore the results of different series are not strictly comparable.

The figures given are relative numbers. They represent the number of cubic centimeters of the thiosulfate solution required for $25 \mathrm{cc}$. of the digesting mixture. Inasmuch as this corresponds to the amount of cuprous oxide, and the latter to the hydrolytic products from the starch, the figures stand for the digestive activity of the enzyme under different conditions. The standard used for comparison contained water instead of one of the salt solutions, but was otherwise the same.

The solutions were all made up by adding to $180 \mathrm{cc}$. of a $1 \%$ starch solution ro cc. of a 2 or $3 \%$ solution of saliva and ro ce. of a salt solution of

1 THrs JournaL, 39, 2745 (I917). 
suitable concentration to wake the final solution $0.01 M$ with respect to the salt.

TABLE I.--EFFECT OF SALTS UPON PTyalin Digestron OF StaRch.

\begin{tabular}{|c|c|c|c|c|c|c|}
\hline \multirow{3}{*}{$\begin{array}{l}\text { Series } \\
\text { No. }\end{array}$} & \multirow{3}{*}{$\begin{array}{l}\text { Solutions } \\
0.01 M \text {. }\end{array}$} & \multicolumn{5}{|c|}{ Cc. thiosulfate solution. } \\
\hline & & $1 \mathrm{hr}$. & $2 \mathrm{hrs.}$ & 4 hrs. & $6 \mathrm{hrs}$. & 24 hrs. \\
\hline & & \multicolumn{5}{|c|}{$0.15 \%$ Saliva. } \\
\hline$I_{n} \ldots \ldots \ldots \ldots$ & $\mathrm{H}_{2} \mathrm{O}$ & 2.3 & $4 . I$ & $7 \cdot 5$ & 9.6 & 15.8 \\
\hline$I \ldots \ldots \ldots \ldots \ldots$ & $\mathrm{NH}_{4} \mathrm{Cl}$ & 16.9 & 23.2 & $23 \cdot 3$ & $23 \cdot 4$ & 26.0 \\
\hline$i \ldots \ldots, \ldots \ldots$ & $\mathrm{NH}_{4} \mathrm{NO}_{3}$ & 12.7 & 18.3 & 22.7 & $23 \cdot 5$ & $25 \cdot 4$ \\
\hline $2 \ldots \ldots \ldots \ldots$ & $\mathrm{H}_{2} \mathrm{O}$ & 7.2 & 10.6 & $15 \cdot x$ & 17.8 & 22.0 \\
\hline$z \ldots \ldots \ldots \ldots \ldots$ & $\left(\mathrm{NH}_{4}\right)_{2} \mathrm{SO}_{4}$ & 3.0 & $\mathrm{I} 2.7$ & I6. $\mathrm{x}$ & I9.5 & 23.9 \\
\hline $2 \ldots \ldots \ldots \ldots$ & $\mathrm{NH}_{4} \mathrm{SCN}$ & 9.0 & 15.7 & 20.8 & $\cdot 22.6$ & 25.6 \\
\hline $3 \ldots \ldots \ldots \ldots$ & $\mathrm{H}_{2} \mathrm{O}$ & $2 \cdot 3$ & $4 \cdot 3$ & $7 \cdot 4$ & $5 \cdot 5$ & $\cdots$ \\
\hline $3 \ldots \ldots \ldots \ldots$ & $\mathrm{NH}_{4} \mathrm{C}_{2} \mathrm{H}_{3} \mathrm{O}_{2}$ & 3.2 & 5.5 & 9.2 & II 4 & $\cdots$ \\
\hline $3 \ldots \ldots \ldots \ldots$ & $\left(\mathrm{NH}_{4}\right)_{2} \mathrm{C}_{2} \mathrm{O}_{4}$ & 3.0 & 5.0 & 7.2 & 8.5 & $\cdots$ \\
\hline $4 \ldots \ldots \ldots \ldots$ & $\mathrm{H}_{2} \mathrm{O}$ & 2.9 & 4.9 & 7.8 & 9.2 & $\cdots$ \\
\hline $4 \ldots \ldots \ldots \ldots$ & $\mathrm{NH}_{4} \mathrm{C}_{2} \mathrm{H}_{3} \mathrm{O}_{2}$ & 5.2 & 7.6 & 11.4 & $14 \cdot 3$ & $\cdots$ \\
\hline $4 \ldots \ldots \ldots \ldots$ & $\left(\mathrm{NH}_{4}\right)_{2} \mathrm{C}_{4} \mathrm{H}_{4} \mathrm{O}_{6}$ & $4 \cdot 5$ & $6 . I$ & 8.1 & 10.3 & $\cdots$ \\
\hline \multicolumn{7}{|c|}{$0.10 \%$ Saliva. } \\
\hline $5 \ldots \ldots \ldots \ldots \ldots$ & $\mathrm{H}_{2} \mathrm{O}$ & 5.6 & 9.8 & $\times 5.6$ & 18.4 & $24 \cdot 1$ \\
\hline $5 \ldots \ldots \ldots \ldots \ldots$ & $\mathrm{NH}_{4} \mathrm{~F}$ & 2.4 & 3.2 & 5.2 & $6 . \mathrm{I}$ & 9.3 \\
\hline $5 \ldots \ldots \ldots \ldots \ldots$ & $\mathrm{NH}_{4} \mathrm{Cl}$ & 22.4 & 24.6 & 25.7 & 26.5 & 30.4 \\
\hline $5, \ldots \ldots \ldots \ldots$ & $\mathrm{NH}_{4} \mathrm{Br}$ & 22.2 & $24 \cdot 5$ & 26.4 & 27.2 & 30.6 \\
\hline $6 \ldots \ldots \ldots \ldots$. & $\mathrm{H}_{2} \mathrm{O}$ & 10.6 & I $3 \cdot 5$ & 19.0 & $2 \pi \cdot 4$ & 25.5 \\
\hline $6 \ldots \ldots \ldots \ldots \ldots$ & $\mathrm{NaF}$ & 3.8 & $4 \cdot 7$ & $7 \cdot 3$ & 9.0 & 14.5 \\
\hline $6 \ldots \ldots \ldots \ldots$ & $\mathrm{NaCl}$ & $23 \cdot 4$ & 24.2 & 26.1 & 26.5 & 31.0 \\
\hline $6 \ldots \ldots \ldots \ldots$ & $\mathrm{NaBr}$ & 22.5 & 24.0 & 2.5 .8 & 26.6 & 30.9 \\
\hline $7 \ldots \ldots \ldots \ldots$ & $\mathrm{NH}_{4} \mathrm{NO}_{3}$ & I2.8 & 17.8 & $23 \cdot 3$ & 24.8 & $27 \cdot 4$ \\
\hline $7 \ldots \ldots \ldots \ldots$ & $\mathrm{NaNO}_{3}$ & I2.8 & 17.6 & 22.5 & 24.2 & 26.9 \\
\hline $7 \ldots \ldots \ldots \ldots$ & $\left(\mathrm{NH}_{4}\right)_{2} \mathrm{SO}_{4}$ & 7.6 & 10.2 & 14.5 & I 7.0 & 23.2 \\
\hline $7 \ldots \ldots \ldots \ldots$ & $\mathrm{Na}_{2} \mathrm{SO}_{4}$ & $7: 4$ & IO.I & 13.9 & I 6.8 & 22,2 \\
\hline \multicolumn{7}{|c|}{ O.I $5 \%$ Saliva. } \\
\hline $8 \ldots \ldots \ldots \ldots \ldots$ & $\mathrm{H}_{2} \mathrm{O}$ & $7 \cdot 7$ & I I.9 & 15.9 & I 8.2 & 23.9 \\
\hline $8 \ldots \ldots \ldots \ldots$ & $\mathrm{NH}_{4} \mathrm{C}_{2} \mathrm{H}_{3} \mathrm{O}_{2}$ & 8.1 & 12.0 & 16.3 & 18.8 & $24 \cdot I$ \\
\hline $8 \ldots \ldots \ldots \ldots$ & $\mathrm{NaC}_{2} \mathrm{H}_{3} \mathrm{O}_{2}$ & 7.8 & II .7 & 15.4 & 18.3 & 23.7 \\
\hline $8 \ldots \ldots \ldots \ldots \ldots$ & $\mathrm{NH}_{4} \mathrm{Cl}$ & $2 I, 2$ & $24 \cdot 3$ & 24.8 & $25 \cdot 4$ & 28.5 \\
\hline $8 \ldots \ldots \ldots \ldots \ldots$ & $\mathrm{NaCl}$ & $22 \cdot 5$ & 24.6 & 24.8 & $25 \cdot 4$ & 28.3 \\
\hline $9 \ldots \ldots \ldots$ & $\mathrm{I}_{2} \mathrm{O}$ & $2 \cdot 3$ & $3 \cdot 7$ & 6.5 & 8.3 & 18.3 \\
\hline $9 \ldots \ldots \ldots \ldots$ & $\mathrm{CaCl}_{2}$ & $15 \cdot 3$ & $20 . I$ & $24 \cdot I$ & 24.8 & 26.2 \\
\hline $9 \ldots \ldots \ldots \ldots$ & $\mathrm{KCl}$ & T 5.8 & 20.5 & 23.8 & 24.8 & 26.2 \\
\hline $9 \ldots \ldots \ldots \ldots . . . .$. & $\mathrm{NaCl}$ & I 5.8 & 20.6 & 23.9 & 24.8 & 26.3 \\
\hline
\end{tabular}

From Series $I$ it is evident that both ammonium chloride and ammonium nitrate markedly increase the hydrolytic action of ptyalin upon starch. Series 2 shows that ammonium sulfate and ammonium thiocyanate also distinctly increase the activity of the ptyalin, although not to such a degree as do the chloride and nitrate. The salts of the organic acids, as shown in Series 3 and 4 , for the most part, have a much smaller effect 
than do those of the inorganic acids. Ammonium acetate shows some power as an auxoamylase; the oxalate does not. Ammonium tartrate has a slight stimulating action.

As is seen in Series 5, of the ammonitum halides the chloride and bromide produce a considerable increase in the amount of starch hydrolyzed, and the quantity of reducing products is the same with the two. The salt of the relatively weak hydrofuoric acid inhibits the action of ptyalin. Comparison of Series 5 and 6 shows that sodium halides resemble the corresponding ammonium compounds, the chloride and bromide increasing the activity of the amylase, the fltoride decreasing it. This similarity is also brought out in Series 7 , where the nitrates and sulfates of the two cations are tested with the same saliva. Both increase the starch-splitting power of the enzyme but not to the same extent, the hydrolysis varying with the anion. Series 8 shows a similar relationship between the ammonium and sodium salts of acetic and hydrochloric acid. The acetates have little influence; the chlorides have a considerable and practically the same influence.

A comparison of the neutral metallic chlorides, as seen in Series 9, shows no variation with the valence of the cation, potassium, sodium and calcium manifesting no difference in their modification of the enzyme activity.

Variations in ptyalin activity in the presence of these salts, then, are not a function of the ammonitum ion but of the anion. The salts of the other alkali metals have the same power as the ammonium salts. The effect is greatest in the case of saits of the strong acids, hydrochloric, hydrobromic and nitric. It is considerable with the sulfates and thiocyanates, both salts of relatively strong acids. The salts of the weak hydrofluoric acid and the still weaker organic acids, like acetic and tartaric, influence the hydrolysis of starch but little or not to a measurable extent. Oxalic acid, however, is an exception to the rule that salts of strong acids are active, the neutral oxalates being without stimulating action upon ptyalin digestion.

Whether the cation is monovalent or bivalent the activating effect is the same, as is shown by comparison of the chlorides of calcium with those of the alkali metals. The trivalent cations were not tested because of the coagulating effect of their soluble salts upon the colloids.

As to the reason for the variations produced by the anion, some change in the colloids suggests itself, either of the starch, or the albumin of the saliva, or both. Yet the evidence of what the nature of such a colloidal change may be is not definite.

That the ammonium ion was not destroyed during the digestion was proved by nesslerizing portions of the digesting mixture at intervals.

I am indebted to Mr. Nao Uyei for the quantitative determinations. 